\title{
Shifting Standards of Judicial Review During the Coronavirus Pandemic in the United States
}

\author{
Wendy K. Mariner \\ Boston University School of Public Health, Boston, Massachuesetts, United States of America \\ Corresponding author: wmariner@bu.edu
}

(Received 23 June 2021; accepted 25 June 2021)

\begin{abstract}
Emergencies are exceptions to the rule. Laws that respond to emergencies can create exceptions to rules that protect human rights. In long lasting emergencies, these exceptions can become the rule, diluting human rights and eroding the rule of law. In the United States, the COVID-19 pandemic prompted states to change rules governing commercial and personal activities to prevent the spread of the coronavirus. Many governors' executive orders were challenged as violations of the constitutionally protected rights of those affected. Judges are deciding whether emergencies can justify more restrictions than would be permitted in normal circumstances and whether some rights deserve more protection than others, even in an emergency. This article analyzes ongoing litigation involving emergency restrictions on religious freedom and access to reproductive health services. These cases suggest that some judges are altering the standards of judicial review of the state's emergency powers in ways that could permanently strengthen some rights and dilute others in normal circumstances.
\end{abstract}

Keywords: Judicial review; constitutional law; pandemic; religious freedom; abortion

\section{A. Introduction}

Judicial review can expand or contract the permissible exercise of state power and protect or diminish human rights. Judicial review establishes standards for determining how important our particular rights are, and how, when and why the state can restrict those rights. These standards are rules that govern our daily lives. But emergencies disrupt our daily lives. Emergencies are exceptions to the rule. Laws that respond to emergencies can create exceptions to rules that protect human rights. Emergencies can justify more coercive measures than would be permitted in normal circumstances. In long lasting emergencies, these exceptions can become the rule, permanently diluting human rights and eroding the rule of law.

Should emergencies change the rules that govern infectious disease control? If so, when and how? Do some rights deserve greater protection than others, even in an emergency? Judges are being asked to decide these questions. How judges frame and analyze the exercise of government authority during an emergency can have long-lasting influence on government power and human

This article is an expanded version of a presentation at the Symposium on The Protection of Human Rights in Infectious Disease Control: Lessons for Global Health Governance from a Comparison of National Judicial Practice, sponsored by the Health and Human Rights Unit, School of Law, and the Centre for Public Health, School of Medicine, Dentistry and Biomedical Sciences, Queen's University Belfast, November 13, 2020. (C) Copyright Wendy K. Mariner 2021.

Wendy K. Mariner Professor Emerita, Health Law, Ethics \& Human Rights, Boston University School of Public Health, Boston, Massachusetts, United States of America.

(C) The Author(s) 2021. Published by Cambridge University Press on behalf of the German Law Journal. This is an Open Access article, distributed under the terms of the Creative Commons Attribution licence (http://creativecommons.org/licenses/by/4.0/), which permits unrestricted re-use, distribution, and reproduction in any medium, provided the original work is properly cited. 
rights. This is especially true when the emergency arises from contagious diseases, such as the coronavirus pandemic that began in late 2019 and has continued well into 2021.

Courts in the United States are reviewing an unprecedented number of legal claims contending that emergency executive orders issued by state governors during the coronavirus pandemic violate constitutionally protected rights. Cases involving two such rights - the right to terminate a pregnancy and the right to freely exercise religion-suggest that certain judges are altering the standards of judicial review of the state's emergency powers in ways that could permanently weaken the former right and strengthen the latter. These decisions suggest that a state of emergency offers the judiciary an opportunity to selectively and permanently expand or diminish protection for rights.

This Article proceeds as follows: Section B summarizes the emergency measures that states in the United States took to control coronavirus spread. Section C explains the methods of analysis or standards of review used by the judiciary to assess what justifies limiting constitutionally protected rights. Section D explores how some courts have lowered the standard of review to limit the constitutional right to terminate a pregnancy during the COVID pandemic. Section E examines a counter example, court decisions making the standard stricter to give greater protection to religious activities. Both trends can threaten public health and undermine human rights. Section $\mathrm{F}$ examines the implications of these examples for judicial review in non-emergencies. The Article concludes that the judiciary need not and should not use a pandemic to alter human rights to protect public health. Doing so threatens not only human rights and public health, but also the integrity of the judiciary.

\section{B. Emergency Orders to Control the Coronavirus Pandemic}

Every country has tried to slow the spread of the SARS-CoV-2 virus. In the United States, control measures included recommendations to wear masks, keep two meters distance from others, and mandatory limits on public gatherings. The Secretary of Health and Human Services declared a national emergency on January 31, 2020, and then President Trump renewed it on July 23, $2020 .^{1}$ These declarations authorized the United States federal government to take dramatic steps to control the pandemic. ${ }^{2}$ Apart from federal legislation providing financial assistance for vaccine development and economic hardship, ${ }^{3}$ however, it took few direct actions. For example, early errors and delays in testing supplies left the country with few options except social distancing-keeping people apart. ${ }^{4}$ For most of 2020 , the federal government left it up to the states to initiate formal mitigation measures. ${ }^{5}$ After Joe Biden became President on January 20, 2021, the federal

\footnotetext{
${ }^{1}$ U.S. Dep't of Health and Human Services, Determination that a Public Health Emergency Exists (Jan. 31, 2020), https:// www.phe.gov/emergency/news/healthactions/phe/Pages/2019-nCoV.aspx; Office of the President, Proclamation 9994 (Mar. 13, 2020) https://www.federalregister.gov/documents/2020/03/18/2020-05794/declaring-a-national-emergency-concerningthe-novel-coronavirus-disease-covid-19-outbreak.

${ }^{2}$ Stafford Act, 51 U.S.C. $\$ \$ 5121-5208$; National Emergencies Act, 50 U.S.C. $\$ \$ 1601-1651$; Defense Production Act, 50 U.S.C. $\$ \$ 4501-4568$.

${ }^{3}$ The President signed legislation in March 2020 providing financial assistance to individuals, businesses, and states and funding for vaccine development and public health programs, although this legislation did not require or use emergency authorization. Families First Coronavirus Response Act, 134 Stat. 177; and the Coronavirus Aid, Relief, And Economic Security (CARES) Act, 134 Stat. 281.

${ }^{4}$ Michael D. Shear, Abby Goodnough, Sheila Kaplan, Sheri Fink, Katie Thomas \& Noah Weiland, The Lost Month: How a Failure to Test Blinded the U.S. to Covid-19, THE NEw YORK TIMEs (Mar. 28, 2020), https://www.nytimes.com/2020/03/28/us/ testing-coronavirus-pandemic.html.

${ }^{5}$ President Trump underplayed the risk of coronavirus transmission, the severity of the pandemic, did not recommend wearing masks, opposed closing schools, churches, and businesses, and persuaded many federal officials-with the exception of Dr. Anthony Fauci-to follow suit, often contrary to their own expert opinions. Juana Summers, Timeline: How Trump Has Downplayed The Coronavirus Pandemic, NPR (Oct. 20, 2020), https://www.npr.org/sections/latest-updates-trump-covid-19results/2020/10/02/919432383/how-trump-has-downplayed-the-coronavirus-pandemic. See generally, Yasmeen Abutaleb \&
} 
government took a more proactive approach, focusing on speeding up vaccine distribution and providing financial assistance to people and businesses in need.

Traditionally, the states have been primarily responsible for controlling infectious diseases, although they have received considerable funding from the federal government to do so. This means that the actions taken by the states to control the coronavirus pandemic come from the same power states have to control infectious disease during ordinary, non-emergency times. ${ }^{6}$ It is the sovereign power to pass laws to protect the health, safety, and welfare of the population in the state, known as the "police power." It is the authority that a state legislature uses to pass virtually all statutes: Criminal laws; state and local tax laws; laws protecting the environment; laws requiring licensure of health facilities and professionals; laws requiring residents to be covered by health insurance; laws requiring vaccinations; and laws governing how to respond to emergencies. Any authority that the federal Constitution does not assign to the federal level of government remains with the states.

In the United States, the coronavirus pandemic and the federal government's limited response prompted state governors to impose rules governing commercial and personal activities to prevent the spread of the coronavirus. By April 2020, all fifty states and the District of Columbia had declared a state of emergency, which authorized their governors to issue executive orders. ${ }^{8}$ Such orders included extending the deadline for receipt of mailed ballots for the November 3, 2020 election, limiting the number of people at public gatherings, in retail businesses, in airlines, trains, buses, worship services, and complete closures of schools, art, entertainment venues, and certain businesses and medical services. ${ }^{9}$ They also recommended that people stay at home, wear masks, and practice social distancing in public. States varied in the measures they chose. Some mandatory measures were expected to be temporary. Some were lifted later in the year to allow businesses to open in order to revitalize a devastated economy. Subsequent waves of increased coronavirus infections, however, persuaded some governors to continue or reimpose restrictions.

\section{Judicial Review of Executive Orders}

Many governors' executive orders were-and still are being — challenged as violations of the constitutionally protected rights of those affected. ${ }^{10}$ Because the executive orders vary in detail from

Damian Paletta, Nightmare Scenario: Inside the Trump Administration's Response to the Pandemic That Changed History (2021).

${ }^{6}$ See generally Wendy E. Parmet, Health Care and the Constitution: Public Health and the Role of the State in the Framing Era, 20 Hastings Const. L. Q. 267 (1992).

${ }^{7}$ Gibbons v. Ogden, 22 U.S. 1, 73 (1824) ("[the police power is] the power of promoting the public welfare by restraining and regulating the use of liberty and property”). See generally Ernst Freund, The PoliCE POWER: PUBLIC POWER AND Constitutional Rights (1904); T.M. Cooley, A Treatise on the Limitations of Police Power in the United States Considered from Both a Civil and Criminal Law Standpoint (1868).

${ }^{8}$ All states have laws authorizing responses to emergencies in general, and many have additional laws specific to public health emergencies, with varying definitions and provisions. Benjamin Della Rocca, Samantha Fry, Masha Simonova \& Jacques Singer-Emery, State Emergency Authorities to Address COVID-19, LAWFARE (May 4, 2020), https://www. lawfareblog.com/state-emergency-authorities-address-covid-19. The Network for Public Health Law, Emergency Declaration Authorities Across All States and D.C., TABLE, https://www.networkforphl.org/wp-content/uploads/2020/01/ Emergency-Declaration-Authorities.pdf. See, e.g., Fabick v. Evers, 956 N.W.2d 856 (Wis. 2021) (interpreting Wisc. Stat. $\$$ 323.10); Desrosiers v. Governor, 486 Mass. 369, 158 N.E.3d 827 (Mass. 2020) (interpreting Massachusetts Civil Defense Act, 1950 Mass. Acts c. 639. $\$ 5$ ).

${ }^{9}$ See Benjamin Della Rocca et al., supra note 8.

${ }^{10}$ See, e.g., League of Indep. Fitness Facilities \& Trainers, Inc. v. Whitmer, 814 Fed. Appx. 125 (6th Cir. 2020) (fitness facilities); Roberts v. Neace, 958 F.3d 409 (6th Cir. 2020) (religious services); Peterson v. Kunkel, 492 F.Supp. 3d 1183 (D.N.M. 2020) (private school); Ass'n of Jewish Camp Operators v. Cuomo, 479 F.Supp. 3d 197 (N.D.N.Y. 2020) (overnight children's camps); Chrysafis v. James, 2021 U.S. Dist. LEXIS 72602, 2021 WL 1405884 (E.D.N.Y. 2021) (eviction proceedings); DeSantis v. Florida Ed. Ass'n, No 1D20-2470 (1st Dist. Ct. App. 2020) (school reopening); County of Butler v. Wolf, 486 F. Supp. 3 d 883 (W.D. Pa. Sept. 14, 2020) (limits on political gatherings and business closures), stay denied, 2020 U.S. Dist. LEXIS 17630 (W.D. 
state to state, judicial decisions are often quite fact specific. ${ }^{11}$ For example, states like New York and California imposed different levels of restrictions in different parts of the state, based on the prevalence of coronavirus cases and deaths. Moreover, few cases reached the United States Supreme Court and fewer have been decided on the merits. ${ }^{12}$ Most were on what is known as the "shadow docket"-emergency appeals from decisions temporarily restraining the enforcement of COVID restrictions pending hearings on the merits. ${ }^{13}$ Nevertheless, even preliminary decisions indicate likely outcomes. Thus, the judiciary plays a pivotal role in deciding which emergency measures are permissible.

A threshold question in most cases was what method of analysis — standard of review - the court should apply to the claim. Judicial decision-making depends almost entirely on the choice of the standard of review. The choice determines the scope of state authority to curtail constitutionally protected rights, including the right to access medical care, freely exercise one's religion, vote, and peaceably assemble. Courts are struggling with the degree to which a pandemic empowers the government to limit the freedom of its population. Under what circumstances? For how long? Does this change the balance between government power and individual rights indefinitely?

This section presents a brief overview of the three general categories of judicial review developed by the U.S. Supreme Court to evaluate claims of infringement of constitutional rights. It then describes a current controversy over what standards of review should apply in emergencies. These cases suggest that the litigants - and perhaps the judges - may be taking advantage of the emergency circumstances to push the standards of judicial review farther in one direction or the other. The outcome will decide the scope of executive power and the human rights of affected individuals beyond the coronavirus pandemic.

\section{Standards of Judicial Review in the United States}

Beginning in the 1960s, the Supreme Court of the United States began developing analytic methods or standards of review by which to assess whether a federal, state, or local law violated a constitutional right. The use of a particular method of analysis was often viewed as preferable to choosing among competing theories of justice that were not universally accepted, or as a way to avoid accusations that the Justices were merely imposing their own personal preferences or philosophies of justice. ${ }^{14}$ In general, each right protected by the United States Constitution is assigned a value-fundamental, important, or ordinary-creating a hierarchy of constitutional rights. ${ }^{15}$ The more important the right, the more justification government needs to restrict it.

Pa. 2020); Dark Storm Indus. LLC v. Cuomo, 2020 U.S. Dist. LEXIS 120514, 2020 WL 3833107 (N.D.N.Y. 2020) (authority to define "essential” services); Bayley’s Campground, Inc. v. Mills, 463 F.Supp. 3d 22 (D. Me. 2020) (camps).

${ }^{11}$ Political opposition to the political party that favored restrictions appears to have motivated many of these challenges. But some seem to be based on conflict between the legislature and the governor as to which branch has the power to decide, regardless of political party. Alan Greenblatt, Political Power Plays: Tension Between the Legislative and Executive Branches Escalates, National Conference of State Legislatures Magazine (Jan., 12 2021), https://www.ncsl.org/ bookstore/state-legislatures-magazine/tension-between-legislative-and-executive-branches-escalates-magazine2021.aspx.

${ }^{12}$ But see religion cases in Part E, infra.

${ }^{13}$ William Baude, Foreword: The Supreme Court's Shadow Docket, 9 N.Y.U. J. L. \& LiBERTy 1, 3-5 (2015) (describing the shadow docket as cases without full briefing or oral argument); Stephen Wermiel, On the Supreme Court's Shadow Docket, the Steady Volume of Pandemic Cases Continues, SCOTUSBLOG (Dec. 23, 2020), https://www.scotusblog.com/2020/12/on-thesupreme-courts-shadow-docket-the-steady-volume-of-pandemic-cases-continues/.

${ }^{14}$ Compare Michael Sandel, Democracy's Discontent, Liberalism and the Limits of Justice (2D ED. 1998); With John Rawls, A Theory of Justice (1971), John Rawls, Political Liberalism (1993); Alasdair Macintyre, After Virtue (1984); Michael Walzer, Spheres of Justice (1983); Robert Nozick, Anarchy, State, and Utopia (1974); Friedrich VON HAyek, The Constitution of Liberty (1972).

${ }^{15}$ Erwin Chemerinsky, The Conservative Assault on the Constitution (2010); Erwin Chemerinsky \& Howard Gillman, The Religion Clauses: The Case for Separating Church and State (2020), Laurence Tribe, The Invisible Constitution (2008), American Constitutional Law, Vol. One (3d ed. 2000). 
The Court has developed a specific standard of review for each right, although the details can shift over time as the standard is refined in Court opinions involving the same right. It is common in law schools in the United States to claim that when Justices decide which standard of review to apply, they have effectively decided the outcome of a case. For this reason, the choice of the standard of review and its components are critical to defining both the content of any constitutionally protected right and the scope of government authority to restrict that right.

The most important rights, often called fundamental, are generally reviewed with "strict scrutiny." These include rights to free speech, free exercise of religion, voting, freedom of the press, freedom to assemble and petition government, freedom from bodily restraint and unreasonable search and seizure, and freedom from discrimination on the basis of race, color, or national origin. ${ }^{16}$ The term strict scrutiny expresses the fact that the Justices look very closely at how a law may infringe on a fundamental right and for what purpose- they strictly scrutinize the law. Generally, to satisfy the strict scrutiny standard, the government must have a "compelling interest" or purpose in enacting a particular law that infringes the right, and the means that the law uses-specifically any restriction on a fundamental right or what the law requires or forbids - must be necessary or narrowly tailored so that the right is not restricted more than necessary to achieve the state's compelling interest. There are variations on how closely the means must fit the purpose, depending on which right is at issue. ${ }^{17}$ In this century, several Supreme Court decisions have expanded the scope and heightened the importance of the right to the free exercise of religion ${ }^{18}$ and the right to freedom of speech, ${ }^{19}$ and imposed more stringent requirements on government to prove that its purposes cannot be achieved some other way without infringing on those rights. In practice, it is exceedingly difficult for government to justify laws that infringe on fundamental rights.

In contrast, rights that are not found by the Court to be very important-not fundamental to democracy-receive "minimum scrutiny", also called rationality review or the rational basis test. These ordinary rights encompass almost all other rights that can be considered aspects of liberty, such as owning property or operating a business. The Court has considered most social and economic rights to be ordinary in this sense, contrary to the way they are understood in international human rights law. The human right to health, for example, is not a right deemed protected by the U.S. Constitution. ${ }^{20}$ Minimum scrutiny allows the state to enact laws that infringe on most rights as long as the government has a "legitimate interest" or goal and the law is rationally related to that

\footnotetext{
${ }^{16}$ United States v. Carolene Prod. Co., 304 U.S. 144, 152, (1938). These are primarily the civil and political rights included in the Universal Declaration of Human Rights, United Nations, UN General Assembly Resolution 217A (III), U.N. GAOR, 3rd Sess. 1st Plenary Meeting, U.N. Doc. A/810, Dec. 10, 1948, and the International Covenant on Civil and Political Rights, G.A. Res. 2200A (XXI), U.N. GAOR, $21^{\text {st }}$ Sess., Supp. No. 16, at 52, UN Doc. A/6316; Dec. 16, 1966 No fundamental right is absolute, but government must demonstrate a compelling reason to justify restriction, such as conviction of a crime to justify incarceration. Supra, note 15. For examples related to health and safety, see generally WENDY K. MARINER ET AL., PUBLIC Health Law, Third Edition (2019).

${ }^{17}$ For example, there are several slightly different standards of review for different types of laws that affect speech. A law that imposes a content-based restriction on freedom of speech, requiring or forbidding certain content in expression, must be "narrowly tailored to achieve compelling state interests." Reed v. Gilbert, Arizona, 135 S. Ct. 2218, 2226 (2015); Nat'l Inst. of Fam. \& Life Advocates v. Becerra, 138 S. Ct. 2361 (2018). In contrast, if content is not regulated, restrictions on the time, place or manner of speech are permissible if they are narrowly tailored to achieve a significant government interest and also leave the speaker ample alternative channels for communication. McCullen v. Coakley, 134 S. Ct. 2518 (2014). Laws restricting speech in the form of advertising are subject to other variations. See e.g., Zauderer v. Off. of Disciplinary Counsel of Supreme Court of Ohio, 471 U.S. 626 (1985) (upholding compelled disclosure of costs in attorney advertising); 44 Liquormart, Inc. v. Rhode Island, 517 U.S. 484 (1996) (striking down ban on advertising liquor prices).

${ }^{18}$ See, e.g., Masterpiece Cakeshop Ltd. v. Colorado Civil Rights Comm'n, 138 S. Ct. 1719 (2018); Burwell v. Hobby Lobby Stores, Inc., 134 S. Ct. 2751 (2014).

${ }^{19} \mathrm{See}$, e.g., Janus v. American Fed'n of State, County, \& Municipal Employees, 138 S. Ct. 2448 (2018); Nat'l Inst. of Family \& Life Advocates v. Becerra, 138 S. Ct. 2361 (2018); McCullen v. Coakley, 134 S. Ct. 2518 (2014); Sorrell v. IMS Health Inc., 563 U.S. 552 (2011); Citizens United v. Federal Election Comm'n, 558 U.S. 310 (2010); Ward v. Rock Against Racism, 491 U.S. 781 (1989).

${ }^{20}$ Int'l Covenant on Economic, Social, and Cultural Rights of its Twenty-First Session, G.A. Res. 2200A (XXI), U.N. GAOR, Supp. No. 16, at 49, U.N. Doc. A/6316 (Dec. 16, 1996); General Comment 14, U.N. Econ. \& Soc. Council, Sub-Comm. on
} 
goal. The law does not have to be necessary to achieve its goal, as long as the approach appears to be a plausible way to serve the purpose and is not irrational. This is the standard of review most often applicable to regulations governing commercial endeavors, from licensure requirements for businesses and professions to rules for vehicular traffic. The standard allows government a great deal of discretion. In practice, those challenging the law have the nearly impossible burden of proving that the government's goal is not legitimate or that the law is arbitrary or an irrational way to achieve the goal. They rarely succeed.

Between these two general classifications is a smaller category of rights that are viewed as more valuable than ordinary rights, but not fundamental, such as commercial advertising, ${ }^{21}$ freedom from gender-based discrimination, ${ }^{22}$ and freedom from involuntary detention of a person with mental illness who is likely to pose a danger to others. ${ }^{23}$ These are sometimes called important rights and are reviewed with heightened or intermediate scrutiny, which generally demands that government show an "important" purpose and that the means to achieve that purpose are substantially likely to achieve that purpose. In this arena, there is more variability, with the Supreme Court heightening the demands for proof in proportion to its view of the importance of each right. $^{24}$

\section{Theories of Judicial Review in Emergencies}

A threshold question is whether there should be a different standard of review in emergencies, and, if so, in all or just some types of emergencies. Before the coronavirus pandemic, most cases and articles addressing emergency powers in the United States considered measures taken to protect national security, such as responses to the terrorist event on September 11, 2001. ${ }^{25}$ Responses to local emergencies, like hurricanes and floods, generally enjoyed public support; indeed, the public often demanded more assistance than was made available. ${ }^{26}$ During the SARS and Ebola pandemics, only a few cases were brought to court. They involved individuals who were involuntarily quarantined or isolated by a state because officials believed they might be infected with the pathogen and likely to infect others. ${ }^{27}$ Courts deciding those cases did not consider that the state was exercising emergency powers. Rather, courts applied the normal standard of review for deprivations of an individual's physical liberty based on preventing individuals from infecting others with a contagious disease. That standard was a form of intermediate review, requiring the state to prove both that the individual was infected-or at least exposed-and also likely to behave, voluntarily or involuntarily, so as to infect other people. ${ }^{28}$

Econ., Soc., and Cultural Rights, Report on the Twenty-Second, Twenty-Third and Twenty-Fourth Sessions, U.N. Doc. E/2001/ 22-E/C.12/2000/21, Annex IV, 8 (2001).

${ }^{21}$ Central Hudson Gas \& Elec. Corp. v. Pub. Serv. Comm'n of N.Y., 447 U.S. 557 (1980).

${ }^{22}$ Craig v. Boren, 429 U.S. 190 (1976).

${ }^{23}$ Foucha v. Louisiana, 504 U.S. 71 (1992).

${ }^{24}$ The Court has occasionally applied a less deferential, more demanding standard than would be required under minimum scrutiny, but without explicitly acknowledging that it is using a heightened form of scrutiny. See, e.g., City of Cleburne v. Cleburne Living Center, 473 U.S. 432 (1985); Plyler v. Doe, 457 U.S. 202 (1982).

${ }^{25}$ See, e.g., Boumediene v. Bush, 553 U.S. 723 (2008) (alien detainees entitled to habeas corpus under U.S. Constitution). See generally Eric A. Posner \& Adrian Vermeule, Security, Liberty, and the Courts; Terror in the Balance (2007); Oren Gross \& Fionnuala Ní Aolaín, Law in Times of Crisis: Emergency Powers in Theory and Practice (2006); Wendy K. Mariner, George J. Annas \& Wendy E. Parmet, Pandemic Preparedness: A Return to the Rule of Law, 1 DreXEL L. REV. 341-82 (2009).

${ }^{26}$ See generally Douglas Brinkley, The Great Deluge: Hurricane Katrina, New Orleans, and the Mississippi GulF COAST (2006).

${ }^{27}$ See Michael R. Ulrich \& Wendy K. Mariner, Quarantine and the Federal Role in Epidemics, 71 SMU L. REV. 391, 403-23 (2018) (describing constitutional standards for involuntary isolation of a person suspected of being infected with a contagious disease).

${ }^{28}$ Id.; Mariner et al., Public Health Law, supra, note 16, at. 63-107. 
Until 2020, the judiciary had seen few challenges to broad measures like closing businesses and restricting public gatherings imposed during the coronavirus pandemic. ${ }^{29}$ When business groups that opposed these restrictions challenged a governors' authority under emergency statutes, the judiciary had almost no precedents to follow. Perhaps needing to respond quickly to urgent complaints, some judges unearthed a 1905 case that few lawyers outside the health law field had read, Jacobson v. Massachusetts. ${ }^{30}$ That case deserves some explanation, because its precedential relevance became a subject of disagreement among judges reviewing COVID cases.

Henning Jacobson objected to a decision by the board of health of Cambridge, Massachusetts, to require city residents - except children with medical contraindications - to be inoculated against smallpox. ${ }^{31}$ A state law authorized the board to impose mandatory vaccination when "necessary for the public health or safety." ${ }^{2}$ The Supreme Court did not second guess the medical decisions at issue. Instead, it noted that the state legislature acted reasonably in determining that vaccination was a reasonable way to limit smallpox transmission and the board's decision to act was reasonable because smallpox was circulating in Cambridge. ${ }^{33}$ The Court recognized that the constitution protected Jacobson's liberty, but found that the state and city had sufficient justification to override his right in those circumstances. ${ }^{34}$ As a result, Jacobson, who was deemed to be a healthy adult, was convicted of noncompliance and fined five dollars. ${ }^{35}$

Jacobson is an awkward and probably inapt precedent for cases challenging COVID pandemic mitigation measures. It was one of the first cases to reach the Supreme Court to challenge the state's power to limit the liberty of its own residents. The Supreme Court did not develop the more precise, tiered standards of judicial review described above until decades after that 1905 case. ${ }^{36}$ Nonetheless, Jacobson is sometimes thought to express a rudimentary precursor to minimum scrutiny, the most deferential standard of review. ${ }^{37}$ The Jacobson decision, however, did not provide a clear principle or standard of review defining what must be proved to justify intruding on the liberty to refuse vaccination. ${ }^{38}$ The opinion included several different phrases drawn from pre-1900 cases involving very different legal issues: a law cannot be "unreasonable, arbitrary and oppressive"; or have no "real or substantial relation" to public health, safety or morals; or be "beyond all question, a plain, palpable invasion of rights secured by the fundamental law." 39 The second quoted phrase requires more justification from government than the Court's current minimum scrutiny does. The last quoted phrase is puzzling, because whether the law is an

\footnotetext{
${ }^{29}$ The United States had not experienced widespread disease from a pandemic since the mis-named Spanish Flu pandemic of 1918. See generally John M. Barry, The Great Influenza: The Epic Story of the Deadliest Plague in History (2004).

${ }^{30}$ Jacobson v. Massachusetts, 197 U.S. 11 (1905).

${ }^{31}$ Henning Jacobson was apparently healthy adult who objected to vaccination because he had had a bad reaction in the past. Id.

${ }^{32}$ Mass. Gen. Laws AnN. ch. 75, § 137.

${ }^{33}$ Vaccination was still rejected or feared by some groups of people at the time, but the Court found that the legislature, not the judiciary, was the proper branch to weigh the merits of inoculation. Jacobson, 197 U.S. at 30, 34-5.

${ }^{34}$ The Court added a caveat: "[T]he police power of a State, whether exercised by the legislature, or by a local body acting under its authority, may be exerted in such circumstances or by regulations so arbitrary and oppressive in particular cases as to justify the interference of the courts to prevent wrong and oppression," and noted specifically its decision should not be read to approve mandatory vaccination of individuals who have a medical condition that could be worsened by vaccination. Id. at 38 .

${ }^{35}$ The Massachusetts Supreme Judicial Court had determined that the statute did not permit forced vaccination; it only required those who failed to be vaccinated to pay a penalty of $\$ 5.00$, about $\$ 142.00$ in 2020 US dollars. Commonwealth v. Pear, 66 N.E. 719, 722 (Mass. 1903).

${ }^{36}$ Wendy K. Mariner, George J. Annas \& Leonard H. Glantz, Jacobson v. Massachusetts: It's Not Your Great-Great Grandfather's Public Health Law, 95 Am. J. Pub. Health 581 (2005).

${ }^{37}$ See, e.g., Laurence O. Gostin \& Lindsay F. Wiley, Pub. Health L. 115-51 (3D ed. 2016).

${ }^{38}$ See generally Lindsey F. Wiley \& Steve Vladeck, Coronavirus, Civil Liberties, and the Courts: The Case Against "Suspending” Judicial Review, 133 HARV. L. REv. 179 (July 2020), https://harvardlawreview.org/wp-content/uploads/2020/ 07/179-198_Online.pdf.

${ }^{39}$ Jacobson, 197 U.S. at 31.
} 
invasion of rights secured by the Constitution is the question presented to the court and not a standard for answering that question. And Jacobson included a caution:

[A]n acknowledged power of a local community to protect itself against an epidemic threatening the safety of all, might be exercised in particular circumstances and in reference to particular persons in such an arbitrary, unreasonable manner, or might go so far beyond what was reasonably required for the safety of the public, as to authorize or compel the courts to interfere for the protection of such persons. ${ }^{40}$

The U.S. Supreme Court has cited Jacobson in several cases, mostly as a non-specific recognition of state authority to protect health and safety, often in a string citation. ${ }^{41}$ Significantly, these cases challenged ordinary laws; they did not involve emergencies. ${ }^{42}$ The only on-point use of Jacobson as precedent was in a very brief 1922 opinion upholding a general statute mandating vaccination against smallpox as a condition of school attendance. ${ }^{43}$ There was no emergency, the vaccination requirement applied at all times, and the Court did not explain its reasoning. The most notorious citation of Jacobson was as authority for upholding the state of Virginia's law authorizing institutions to forcibly sterilize so-called "feebleminded" persons for "the public welfare" in the 1927 case of Buck v. Bell. ${ }^{44}$

Today, minimum scrutiny applies most often to laws regulating commercial entities. That remained true in most cases that upheld the closure of businesses or restrictions on the number of customers during the coronavirus pandemic. ${ }^{45}$ At the beginning of the COVID pandemic, most early cases involving commercial and public gatherings did use Jacobson to support their decision. ${ }^{46}$ However, others found Jacobson inapplicable. ${ }^{47}$ Even applying ordinary modern standards of review, courts typically upheld state measures to control the pandemic, at least in cases involving businesses and entertainment establishments. ${ }^{48}$

\footnotetext{
${ }^{40} I d$. at 32.

${ }^{41}$ See, e.g., Kansas v. Hendricks, 521 U.S. 346, 356 (1997) (discussing civil commitment of sex offender); Hamilton v. Regents of Univ. of Cal., 293 U.S. 245, 264 (1934) (denying religious exemption from military); Stephenson v. Binford, 287 U.S. 251, 272 (1932) (discussing the trucking context); United States v. Macintosh, 283 U.S. 605, 624 (1931) (no citizenship for pacifist); Euclid v. Amber Realty Co., 272 U.S. 365, 379 (1926) (zoning context); Thomas Cusack Co. v. City of Chicago, 242 U.S. 526, 530 (1917); Plymouth Coal Co. v. Pennsylvania, 232 U.S. 531, 542 (1914) (discussing coal mining safety); Sturges \& Burn Mfg. Co. v. Beauchamp, 231 U.S. 320, 325 (1913) (analyzing child labor law); Barnett v. Indiana, 229 U.S. 229 U.S. 26, 28 (1913) (mining context); Schmidinger v. City of Chicago, 226 U.S. 578, 582 (1913) (discussing weight of bread); Collins v. Texas, 223 U.S. 288, 297 (1912) (analyzing medical licensure); German Alliance Ins. Co. v. Hale, 219 U.S. 307, 316 (1911) (insurance context); Welch v. Swazey, 214 U.S. 91, 105 (1909) (discussing building height).

${ }^{42}$ An exception-not related to public health-was Sterling $v$. Constantin, where the Court found no justification for the Texas governor to declare an emergency and halt oil production in order to return oil prices to a decent level during the Great Depression. See Sterling v. Constantin, 287 U.S. 378, 389 (1932).

${ }^{43}$ Zucht v. King, 260 U.S. 174 (1922) (upholding mandatory smallpox vaccination as a condition of school attendance).

${ }^{44}$ Buck v. Bell, 274 U.S. 200 (1927). The decision was also based on mistakes of fact. See generally Paul A. Lombardo, Three Generations, No Imbeciles: New Light on Buck v. Bell, 60 N.Y.U. L. Rev. 30 (1985). The decision has been superseded by later cases protecting personal decisions about medical and reproductive care. Cruzan v. Director, Missouri Dep't of Health, 497 U.S. 261 (1990); Griswold v. Connecticut, 381 U.S. 479 (1965); Skinner v. Oklahoma, 316 U.S. 535 (1942).

${ }^{45}$ Wendy E. Parmet, Rediscovering Jacobson in the Era of COVID-19, 100 B.U. L. REV. 117 (2020).

${ }^{46}$ E.g., Page v. Cuomo, 478 F. Supp. 3d 355, 366 (N.D.N.Y. Aug. 11, 2020); League of Indep. Fitness Facilities \& Trainers, Inc. v. Whitmer, 814 Fed. Appx. 125 (6th Cir. 2020); Six v. Newsom, 462 F. Supp. 3d 1050 (C.D. Cal. 2020).

${ }^{47}$ See e.g., County of Butler v. Wolf, 456 F.Supp. 3d 883, 901 (W.D. Pa. 2020) ("ordinary constitutional scrutiny is necessary to maintain the independent judiciary's role as a guarantor of constitutional liberties-even in an emergency"); Bayley's Campground v. Mills, 463 F.Supp. 3d 22, 32 (D. Me May 29, 2020):

the permissive Jacobson rule floats about in the air as a rubber stamp for all but the most absurd and egregious restrictions on constitutional liberties, free from the inconvenience of meaningful judicial review. This may help explain why the Supreme Court established the traditional tiers of scrutiny in the course of the 100 years since Jacobson was decided.

${ }^{48}$ Desrosiers v. Governor, 486 Mass. 369, 386, fn. 25 (2020) (citing Jacobson, while noting "We agree that Jacobson does not lead us to disregard constitutional scrutiny and defer completely to the executive's orders. Instead, we determine the
} 
In cases involving more important rights, however, the picture is different. Judicial opinions began to debate whether Jacobson should be considered a controlling precedent to give the state maximum discretion in all emergencies. Because Jacobson was not a case about an emergency law, relying on it to determine when the state can interfere with important personal rights suggests that it could apply in ordinary circumstances. The next sections discuss that point.

\section{Judicial Review of Access to Reproductive Care in Emergencies}

Rights that may be diluted as a result of coronavirus pandemic cases are rights to make reproductive decisions, especially the right to decide to have an abortion. Many state executive orders required that non-essential or non-life-preserving businesses close, at least temporarily, during the COVID epidemic. Few laws define essential services, so governors specified the types of businesses that could stay open and those that had to close. In states where the state government is very conservative, the executive orders classified reproductive health clinics as non-essential and required them to close. In particular, they could not perform abortions. The reason given was to preserve the limited supply of personal protective equipment (PPE) in the United States at the beginning of the epidemic in March and April 2020. At the time, hospitals had trouble getting enough PPE. Hospital departments and medical practices stopped seeing patients for routine and elective services, although many shifted to telemedicine and virtual visits via computer platforms. That was not an option for abortion services. Notably, in other states like Massachusetts, abortion services, as well as emergency and critical care services, were deemed essential and allowed to continue, with no apparent impact on PPE supply.

In 2020, two federal courts of appeal discovered the old Jacobson case and concluded that it should control challenges to executive orders classifying reproductive health care as non-essential, because the coronavirus pandemic was an emergency. ${ }^{49}$ The courts used the minimum level of judicial review to uphold clinic closures, largely ignoring the Supreme Court's quite specific standard that applies to laws limiting a woman's right to abortion. About the same time, two different federal courts of appeal rejected Jacobson as controlling precedent. They applied the normal standard of review and struck down executive orders that closed reproductive health facilities. ${ }^{50}$ These conflicting opinions set the stage for reconsidering the extent to which a woman's right to terminate a pregnancy could be curtailed.

The U.S. Supreme Court first recognized the constitutional right of a woman to decide to have an abortion in the 1973 case of Roe v. Wade. ${ }^{51}$ In Roe, it recognized the right as an aspect of liberty protected by the Fifth and Fourteenth Amendments ${ }^{52}$ and described it as a fundamental right. Thus, a form of strict scrutiny applied, requiring the state to demonstrate a compelling interest in regulation and that a restriction is necessary to achieve that interest. The two accepted state

appropriate level of scrutiny and analyze the issues thereunder.”); Carmichael v. Ige, 470 F. Supp. 3d 1133, 1144 , 1147 (D. Haw. 2020) (applying Jacobson, but finding that the state's 14-day quarantine order also survived strict scrutiny); Geller v. DeBlasio, 2020 U.S. Dist. LEXIS 87405 (S.D.N.Y. 2020) (applying intermediate scrutiny “through the lens" of Jacobson).

${ }^{49}$ In re Abbott, 956 F.3d 696 (5th Cir. 2020); In re Rutledge, 956 F.3d 1018 (8th Cir. 2020). The Fifth Circuit includes Louisiana, Mississippi, and Texas and has issued decisions generally favoring restrictions on access to abortion. The Eighth Circuit includes Arkansas, Iowa, Minnesota, Missouri, Nebraska, North Dakota, and South Dakota, and has issued mixed decisions on that issue.

${ }^{50}$ Adams \& Boyle, P.C. v. Slatery, 956 F.3d 913 (6th Cir. 2020), rehearing en banc denied, 956 F.3d 913 (2020); Robinson v. Attorney General, 957 F.3d 1171 (11th Cir. 2020). The Sixth Circuit includes Kentucky, Michigan, Ohio, and Tennessee. The Eleventh Circuit includes Alabama, Florida, and Georgia. Both are thought to lean conservative.

${ }^{51}$ Roe v. Wade, 410 U.S. 113 (1973).

${ }^{52}$ U.S. CONST., amend XIV. "[n]o State shall ... deprive any person of life, liberty, or property, without due process of law; nor deny to any person within its jurisdiction the equal protection of the laws." "Substantive" due process requires government to justify any law that limits a person's liberty, regardless of how fair its enforcement procedures are, because a challenge to such a law is a challenge to the substance of the law. RonALD D. RoTUNDA \& JOHN E. NOWAK, TREATISE ON CONSTITUTIONAL LAW: SubstanCE AND PRocedure 608-29 (1999). 
goals were to protect the life of the woman and to protect the potential life of the foetus. ${ }^{53}$ Moreover, the Court found that the state's interest in protecting the woman's health only became compelling after the first trimester, when the procedure's risks to the woman became equal to or greater than the risks from childbirth. The state's interest in the potential life of the fetus only became compelling at viability - when the fetus could feasibly live outside the womb, with or without mechanical support. Even after viability, abortion could not be forbidden if it was necessary to preserve the woman's life or her physical, emotional, or family life health, because the state still has an interest in protecting the woman's health. ${ }^{54}$

There followed decades of state laws regulating providers of abortion services and imposing conditions on women's access to those services. Dozens of challenges to these laws reached the Supreme Court, which responded by modifying the standard of review and, by implication, the right itself. ${ }^{55}$ In 1992, in Planned Parenthood of Southeastern Pennsylvania v. Casey, the Court stopped referring to the right as fundamental. ${ }^{56}$ This slight shift allowed states to defend increasingly restrictive laws with somewhat less demanding justifications. Casey also reformulated the standard of review for abortion legislation. It allowed regulation that did not impose an "undue burden" on the right:

An undue burden exists, and therefore a provision of law is invalid, if its purpose or effect is to place a substantial obstacle in the path of a woman seeking an abortion before the fetus attains viability.... Unnecessary health regulations that have the purpose or effect of presenting a substantial obstacle to a woman seeking an abortion impose an undue burden on the right. ${ }^{57}$

This formulation dispenses with the need for the state to demonstrate that the purpose of its regulation must meet any specific degree of importance. It also avoids specifying how close the fit must be between the regulation and its purpose. Yet the Court reaffirmed that "a state may not prohibit any woman from making the ultimate decision to terminate her pregnancy before viability." 58

In 2016, the Court appeared to give the Casey standard more teeth in Whole Woman's Health v. Hellerstedt. ${ }^{59}$ The state of Texas required physicians who performed abortions to have admitting privileges at a hospital within thirty miles of their clinic. ${ }^{60}$ This was an impossible requirement to meet. Hospitals almost never grant privileges to physicians who perform abortions, in part because of controversy over abortion. More important, however, outpatient abortion complications are so rare that hospital admission is almost never needed, and hospitals are not inclined to offer privileges to physicians who don't admit patients to hospital. The Court found that this regulation did not promote the state's professed goal of protecting women's health. Instead, it resulted

\footnotetext{
${ }^{53}$ Roe, 410 U.S. at 158 ("the word 'person,' as used in the Fourteenth Amendment, does not include the unborn" and therefore the fetus does not have constitutional rights).

${ }^{54}$ Doe v. Bolton, 410 U.S. 179 (1973).

${ }^{55}$ Mariner et al., Pub.Health Law, supra, note 27, at 355-84.

${ }^{56}$ Planned Parenthood of Southeastern Pennsylvania v. Casey, 505 U.S. 833 (1992).

${ }^{57} I d$. at 877 . The state may not prohibit abortion before fetal viability and may only do so after viability if the regulation still protects the life and health of the woman. $I d$. at 878 .

${ }^{58} I d$. at 877.

${ }^{59}$ Whole Woman's Health v. Hellerstedt, 136 S. Ct. 2922 (2016).

${ }^{60} \mathrm{Physicians}$ who are not hospital employees — which includes many private practices and virtually all abortion providers cannot admit patients to a hospital unless the hospital voluntarily grants them the privilege of admitting patients, typically on the basis of their credentials, experience, the likelihood of sending their patients to that hospital, and the hospital's need for patients in that specialty. American College of Obstetricians and Gynecologists, Hospital Admitting Privileges Mandates Undermine Physician Practice and Unduly Burden Women's Access to Abortion, undated, https://www.acog.org/news/ news-articles/2020/11/hospital-admitting-privilege-mandates-undermine-physician-practice-and-unduly-burden-womensaccess-to-abortion.
} 
in the closure of abortion providers in the state, thereby creating an unconstitutional undue burden on the right. ${ }^{61}$ The Court held that Casey "requires that the courts consider the burdens a law imposes on abortion access together with the benefits those laws confer." 62 This weighing of burdens and benefits requires analyzing the facts. Laws that create obstacles without achieving demonstrable benefits to women's health are unnecessary and unconstitutional.

The Court upheld the Whole Woman's Health formulation of the undue burden test in June Medical Services $v$. Russo, a 2020 case striking down an almost identical law in Louisiana. ${ }^{63}$ The majority emphasized that, to be constitutional, the benefits that the law produces must outweigh the burdens that it places on access to abortion. However, the concurring and dissenting opinions strongly suggested that the conservative Justices were rethinking just how fact-based the standard should be. Indeed, there were at least five different views of how the standard should be interpreted and applied. Chief Justice Roberts, who had dissented in Whole Woman's Health, provided the fifth vote to strike down the Louisiana law, but only on the basis of stare decisis, because the Texas and Louisiana laws were almost identical. In his concurrence, he found the Whole Woman's Health balancing of benefits and burdens inappropriate for the judiciary. Instead, he would focus on whether a law creates a substantial obstacle. He would not require states to prove that restrictions on abortion would actually promote women's health in fact. He wrote, "Laws that do not pose a substantial obstacle to abortion access are permissible, so long as they are 'reasonably related' to a legitimate state interest." 64 This describes the minimum scrutiny standard of review for any law that imposes delays, costs, or conditions that are not seen as a "substantial obstacle." It also indicates that the right to decide to terminate a pregnancy should be considered merely an ordinary right, not fundamental or even important.

Thus, the new majority of Justices who oppose abortion appear poised to continue to dilute Roe's standard of review. The cases challenging executive orders that closed or postponed abortion services during the COVID pandemic offered the opportunity to do just that. The threshold question in four key cases was what standard to use to review COVID closures of reproductive health clinics. All four appellate court decisions were interlocutory, granting or denying a temporary restraining order or writ of mandamus pending hearings on the merits. Nonetheless, such procedural decisions required deciding whether either party was likely to succeed on the merits, thereby indicating the court's probable future conclusion. ${ }^{65}$

In the case of In re Abbott, reproductive health centers challenged the Texas governor's designation of their abortion services as "not immediately medically necessary," requiring them to close during the emergency in order to preserve PPE. ${ }^{66}$ The center argued that its services were time sensitive and used minimal PPE, far less than the PPE needed for childbirth or surgery. ${ }^{67}$

\footnotetext{
${ }^{61}$ The Court also struck down a provision of the Texas law that required out-patient abortion facilities to comply with the physical and staffing standards of an ambulatory surgical center. $136 \mathrm{~S}$. Ct. at 2318. Like the privileges requirement, these licensure standards were not necessary to protect women's health and were sufficiently expensive and disruptive to drive providers out of business. $I d$.

${ }^{62} \mathrm{Id}$. at 2309.

${ }^{63}$ June Medical Services v. Russo, 140 S. Ct. 2103 (2020).

${ }^{64} I d$. at 2135 (Roberts, C.J., concurring).

${ }^{65}$ Litigants seeking a preliminary injunction against enforcement of a law typically must show: A strong likelihood of success on the merits; the likelihood that they will suffer irreparable harm absent relief; opposing parties will not be harmed; and an injunction is in the public interest. Nken v. Holder, 556 U.S. 418, 425-26 (2009) (injunction); Winter v. National Resources Defense Council, 555 U.S. 7, 22 (2008) (injunction pending appeal); Cheney v. U.S. Dist. Ct. D.C., 542 U.S. 367,380 (2004) (writ of mandamus).

${ }^{66}$ In re Abbott, 954 F.3d 772 (5th Cir. 2020) (Abbot II) (granting writ of mandamus vacating lower court's temporary restraining order that halted executive order); 956 F.3d 696 (5th Cir. 2020) (Abbott V) (granting new writ of mandamus after remand).

${ }^{67} \mathrm{See}$ American College of Obstetrics \& Gynecology, Joint Statement on Abortion Access During the COVID-19 Outbreak (Mar. 18, 2020); https://www.acog.org/news/news-releases/2020/03/joint-statement-on-abortion-access-during-the-covid-19outbreak. Timely access was important because Texas law banned procedural abortion after 22 weeks of pregnancy, with few
} 
Moreover, closing abortion services would actually increase the risk of COVID transmission, because women would travel to open sites in other states to obtain timely abortions. Closing the services would undermine, rather than help, the state's goal. Under Casey's principles, the order offered no benefit, but instead imposed a significant burden on the right to terminate pregnancies.

The Fifth Circuit Court of Appeals rejected that argument. It held that Jacobson established "the framework governing emergency exercises of state authority during a public health crisis." 68 The conclusion that Jacobson governed all emergency measures was a dramatic departure from precedent; Jacobson had not previously been viewed as an emergency case. The court paid lip service to Casey and Whole Woman's Health, but quoted phrases from Jacobson to craft a standard of review like minimum scrutiny. ${ }^{69}$ It held, "A court should 'ask[ ] whether [the order] imposes burdens on abortion that 'beyond question' exceed its benefits in combating the epidemic."70 That demands that challengers produce a much higher level of proof than Whole Woman's Health required. Finding that the order was merely temporary, the court concluded that courts may ask only whether the state has acted in an "arbitrary, unreasonable manner."71 The court's formulation gives the state the widest discretion, regardless of the importance of the right: "Jacobson instructs that all constitutional rights may be reasonably restricted to combat a public health emergency." ${ }^{2}$ It sustained the closures pending a hearing on the merits. The Eighth Circuit Court Of Appeals, in In re Rutledge, quickly adopted the reasoning of In re Abbott and, applying Jacobson, allowed Arkansas's emergency ban on abortion services to remain in effect. ${ }^{73}$

Two other federal appellate courts came to the opposite conclusion. They upheld preliminary injunctions against emergency bans on abortion procedures during the COVID-19 pandemic. One day after the Rutledge decision, the Federal Court of Appeals for the Eleventh Circuit in Robinson v. Attorney General found that Jacobson's "ruling was not a blank check for the exercise of governmental power." 74 The court approved the Casey standard to assess whether against Alabama's emergency ban on abortion procedures would impose an undue burden on women's rights. Finding that it likely would, the court allowed a preliminary injunction to remain in effect pending appeal. ${ }^{75}$

exceptions, Tex. Health \& Safety Code $\$ \$ 171.044,171.042$, and also banned medication abortion after 10 weeks of pregnancy, Tex. Health \& Safety Code $\$ 171.063(\mathrm{a})(2)$.

${ }^{68}$ Abbott II, 754 F.3d at 783; Abbott V, 756 F.3d at 710.

${ }^{69}$ Abbott V, 956 F.3d at 705, quoting Jacobson, 197 U.S. at 31,

[W] hen faced with a society-threatening epidemic, a state may implement emergency measures that curtail constitutional rights so long as the measures have at least some 'real or substantial relation' to the public health crisis and are not 'beyond all question, a plain and palpable invasion of rights secured by the fundamental law';

Abbott II, 954 F.3d at 783, quoting Jacobson, 197 U.S. at 29,

in every well-ordered society charged with the duty of conserving the safety of its members the rights of the individual in respect of his liberty may at time, under the pressure of great dangers, be subjected to such restraint, to be enforced by reasonable regulations, as the safety of the general public may demand.

Judge James Dennis dissented, arguing that the district court did not abuse its discretion in issuing the TRO, and that the majority treated abortion services differently without justification, second guessed the trial court's evaluation of the evidence, and improperly granted the extraordinary remedy of mandamus. Abbott V, 956 F.3d. at 724-739 (Dennis, J., dissenting).

${ }^{70}$ Abbott V, 956 F.3d at 705 (quoting Abbott II, 954 F.3d at 784).

${ }^{71}$ Abbott V, 956 F.3d at 734 (quoting Jacobson, 197 U.S. at 28). See also Abbott II, 954 F.3d at 784 (“Jacobson disclaimed any judicial power to second-guess the state's policy choices in crafting emergency public health measures").

${ }^{72}$ Abbott II, 954 F.3d at 786.

${ }^{73}$ In re Rutledge, 946 F.3d 1018, 1027-28 (8th Cir. 2020) (granting writ of mandamus dissolving a temporary restraining order that had halted enforcement of the ban on procedural abortions in Arkansas, characterizing them as elective or nonemergency procedures).

${ }^{74}$ Robinson v. Attorney General, 957 F.3d 1171, 1179 (11th Cir. 2020) ("[J]ust as constitutional rights have limits, so too does a state's power to issue executive orders limiting such rights in times of emergency.").

${ }^{75} I d$. at 1181 . 
The Federal Court of Appeals for the Sixth Circuit explained its similar conclusion in more detail in Adams \& Boyle v. Slatery, a challenge by reproductive health clinics to the Tennessee governor's emergency ban on abortion procedures. ${ }^{76}$ As in all these cases, the state's goal was to preserve PPE and prevent community spread of COVID. Tennessee argued that Jacobson should control the decision and allow the ban to stand. ${ }^{77}$ The court stressed the difficulty of applying Jacobson to the dramatically different facts before it. It concluded that even if Jacobson is accepted "at face value," a woman's right to a pre-viability abortion is part of "the fundamental law." After all, the court noted, ordinarily the governor's order would be an unconstitutional ban on abortion, even if time-limited. The order "that would prevent a woman from exercising her right in-state altogether, or would require her to undergo a more invasive and costlier procedures than she otherwise would have[-] constitutes 'beyond question, a plain, palpable invasion of rights secured by [that] fundamental law."'78 Although the court recognized that "abortion rights during a public health crisis" may not necessarily be "identical to rights during normal times," it "will not countenance ... the notion that COVID-19 has somehow demoted Roe and Casey to second-class rights, enforceable against only the most extreme and outlandish violations." 79

Immediately after the Abbott $V$ decision, Texas Governor Abbott ended his executive order. Then, on January 25, 2021, in a three sentence per curiam decision without opinion, the U.S. Supreme Court granted certiorari in the Texas case, vacated the Abbot $V$ judgment below, and remanded to the Fifth Circuit with instructions to dismiss the case as moot. ${ }^{80}$ It did the same with Slatery for the same reason.

The absence of a U.S. Supreme Court decision on the merits leaves lower courts struggling with how to analyze similar cases. Some courts have concluded that the vacated decisions in Abbott and Rutledge cannot be used precedents. ${ }^{81}$ But others have continued to use Jacobson as a general framework for emergencies. ${ }^{82}$

It seems possible that the judges who allowed the closure of clinics used the COVID epidemic to dilute the importance of the right to make reproductive decisions. These appellate judges used a form of minimum scrutiny as the standard of review and did not require government to prove that closing clinics would preserve any PPE or prevent the spread of COVID. They and lower courts judges often used facts selectively, ignoring medical evidence and emphasizing the temporary nature of closures. Because abortion is a time sensitive procedure, however, such limits effectively prohibit many women from exercising their right to obtain an abortion. Keeping clinics closed during an emergency has the same effect on women as prohibiting abortion services in nonemergency.

\footnotetext{
${ }^{76} 956$ F.3d 913 (6th Cir. 2020) (denying the state's appeal of the district court preliminary injunction against executive order).

${ }^{77} I d$. at 918 (noting the state's characterization of abortions as "surgical and invasive procedures that are elective and nonurgent").

${ }^{78} I d$. at 926 (quoting Jacobson, 197 U.S. at 31).

${ }^{79} \mathrm{Id}$. at 927.

${ }^{80}$ Planned Parenthood Center for Choice v. Abbott, 141 S.Ct. 1261 (2021) (citing United States v. Munsingwear, Inc. 349 U.S. 36 (1950)). The Supreme Court is not required to hear appeals except in specific types of cases, and these did not fall into that category. Moreover, because the orders were no longer in effect, the challengers were no longer subject to their restrictions.

${ }^{81}$ Forbes v. County of San Diego, 2021 U.S. Dist. LEXIS 41687, 2021 WL 843175 (S.D. Cal. 2021); New Orleans Catering, Inc. v. Cantrell, 2021 U.S. Dist. LEXIS 38516, 2021 WL 795979 (2021); Grisham v. Romero, 2021 N.M.LEXIS 3, 2021 WL 608790 (N.M. 2021); Let Them Play Mn v. Walz, 2021 U.S. Dist. LEXIS 23485, 2021 WL 423923 (D. Minn. 2021).

${ }^{82}$ See, e.g., Big Tyme Investments v. Edwards, 985 F.3d 456 ( $5^{\text {th }}$ Cir. 2021); Sanchez v. Brown, 2020 U.S. Dist. LEXIS 90667 (N.D. Tex. 2020).
} 


\section{E. Judicial Review of Religious Freedom in Emergencies}

The second example of altering standards of review concerns religious objections to public health measures. Emergency orders by state governors banned or limited the number of people who are allowed to attend public gatherings in person during the COVID epidemic. Places of worship were often included. They present particular risks, because people from different households typically gather close together for a prolonged periods, usually an hour or more, praying and singing, traditionally without masks. ${ }^{83}$ Multiple outbreaks of infection have been traced to churches. ${ }^{84}$ Some religious institutions-mostly Christian churches-challenged their state's executive orders, claiming that limits on in-person attendance at church services violated their right to exercise their religion, which is protected by the First Amendment of US Constitution. ${ }^{85}$ Many lower court decisions held that the limits on attendance were entirely justified on the basis of scientific facts about coronavirus transmission. ${ }^{86}$ Ultimately, three cases reached the United States Supreme Court.

The standard of review that the United States Supreme Court had applied to laws that have a secular purpose, but may affect religious practices, has been the relatively deferential minimum scrutiny. ${ }^{87} \mathrm{~A}$ law that is "neutral and generally applicable" is justifiable as long as the state has a legitimate purpose and the law's requirements or prohibitions are "rationally related" to furthering that purpose.$^{88} \mathrm{~A}$ law is neutral toward religion when it does not single out religion for disfavored treatment or burdens. ${ }^{89}$ It is generally applicable when it applies to the general population or similarly situated entities that are not religious. ${ }^{90}$ Such a law is constitutional even if it inconveniences religious practices. Classic examples include public health laws, such as mandatory vaccinations. ${ }^{91}$ In contrast, laws that are not neutral or that target religion for particular burdens are reviewed using strict scrutiny. ${ }^{92}$

Recently, however, a new conservative majority of Justices issued decisions that characterized generally applicable laws as not neutral toward religion. The opinions suggested that these Justices were privileging religious beliefs over general laws intended to protect public welfare, such as laws

\footnotetext{
${ }^{83}$ Brief of American Medical Association as Amicus Curiae in Support of Respondent, Roman Catholic Diocese of Brooklyn v. Cuomo (2020) (No. 20A87), https://www.supremecourt.gov/DocketPDF/20/20A87/161064/20201118104326342 20A87acAmericanMedicalAssociationAndMedicalSocietyOfTheStateOfNewYork.pdf, (summarizing evidence).

${ }^{84}$ Brenda Gregorio-Nieto \& NBC 7 Staff, Health Officials Alert Public Over 2 Additional Outbreaks at Awaken Church Locations, NBC SAN DIEGO, (Dec. 3, 2020), https://www.nbcsandiego.com/news/local/health-officials-alert-public-over-2 additional-outbreaks-at-awaken-church-locations/2460223/?amp; Kate Conger, Jack Healy \& Lucy Thompkins, Churches Were Eager to Reopen. Now They Are Confronting Coronavirus Cases, New YoRK Times (July 8, 2020), https://www. nytimes.com/2020/07/08/us/coronavirus-churches-outbreaks.html; CDC, High COVID-19 Attack Rate Among Attendees at Events at a Church - Arkansas, March 2020, Morbidity \& MORTALITy RePORT 632, 69(20) (May 22, 2020), https://www. cdc.gov/mmwr/volumes/69/wr/mm6920e2.htm.

${ }^{85} \mathrm{See}$ U.S. CONST., amend I. (stating "Congress shall make no law respecting the establishment of religion, or prohibiting the free exercise thereof; or abridging the freedom of speech or of the press; or the right of the people peaceably to assemble, and to petition the Government for a redress of grievances.")

${ }^{86}$ See, e.g., Robinson v. Murphy, 2020 U.S. Dist. LEXIS 185070, 2020 WL 5884801 (D.N.J. 2020) (denied TRO against N.J. restrictions on worshipers because same rules applied to similar secular gatherings), vacated, 141 S.Ct. 972 2020), remanded for reconsideration in light of Roman Catholic Diocese); South Bay United Pentecostal Church v. Newsom, 494 F. Supp. $3 \mathrm{~d} 785$ (S.D. Cal. 2020) (citing Jacobson), vacated and remanded, 141 S. Ct. 716 (2021).

${ }^{87}$ Prince v. Massachusetts, 321 U.S. 158, 166-67 (1944) (citing Jacobson stating, "[a parent] cannot claim freedom from compulsory vaccination for the child more than for himself on religious grounds. The right to practice religion freely does not include liberty to expose the community or the child to communicable disease or the latter to ill health or death.").

${ }^{88}$ Unemployment Div., Dep't Hum. Res. of Oregon v. Smith, 494 U.S. 872 (1990).

${ }^{89}$ Church of Lukumi Babalu Aye, Inc. v. City of Hialeah, 508 U.S. 520 (1993); Trump v. Hawaii, 138 S. Ct. 2392 (2018).

${ }^{90}$ Unemployment Division, supra, note 88.

${ }^{91}$ Phillips v. City of New York, 775 F.3d 538 (2d Cir. 2015), reh. and reh. en banc denied (2015), cert. den. 136 S. Ct. 104 (2015); Brown v. Stone, 378 So.2d 218 (Miss. 1979); Jacobson v. Massachusetts, 197 U.S. 11 (1905).

${ }^{92}$ See Mariner et al., Public Health Law, supra, note 16, at 492-533.
} 
prohibiting discrimination on the basis of race, color, sex, or disability, ${ }^{93}$ and laws requiring health insurance to cover contraceptives. ${ }^{94}$ The challenges to COVID restrictions gave these Justices an opportunity to strengthen protection of religious beliefs, although not without resistance from their fellow Justices. Most cases involved whether to grant or deny an injunction or a stay of a lower court decision pending review on the merits. The Justices do not often explain their reasoning in procedural matters. But in these cases, they made their views clear in concurring and dissenting opinions.

The contrasting views first appeared in South Bay Pentecostal United Church v. Newsom (South Bay I). ${ }^{95}$ There, Chief Justice Roberts wrote a brief concurrence agreeing with the per curiam decision not to stay enforcement of a California executive order limiting religious and other nonessential services during the pandemic. He said, our Constitution principally entrusts " $[t]$ he safety and the health of the people" to the politically accountable officials of the States "to guard and protect," and they must have "especially broad" latitude, particularly where pandemics are "dynamic and fact-intensive." ${ }^{96}$ Notably, he cited Jacobson v. Massachusetts. Three Justices disagreed. Justice Kavanaugh wrote a dissent, joined by Justices Thomas and Gorsuch, arguing that claims of violations of religious freedom must be judged using the strict scrutiny standard. ${ }^{97} \mathrm{He}$ and Roberts chose different comparators for assessing discrimination. Kavanaugh claimed that worship services were limited to the lower of one hundred people, or twenty-five percent of the building's seating capacity, while secular businesses like retail stores and restaurants were not, and therefore California's guidelines discriminated against places of worship. Roberts wrote that religions were treated the same or better than "comparable secular gatherings, including lectures, concerts, movie showing, spectator sports, and theatrical performances, where large groups of people gather in close proximity for extended periods of time." ${ }^{98} \mathrm{He}$ characterized grocery stores, banks, and laundromats as dissimilar.

The same split appeared in a similar case from Nevada, Calvary Chapel Dayton Valley v. Sisolak, which denied an injunction against a Nevada order limiting worship attendance to fifty persons. ${ }^{99}$ Justices Thomas, Alito, Gorsuch, and Kavanaugh dissented. Justice Alito's dissent, joined by Justices Thomas and Kavanaugh, pointed out that casinos, bowling alleys, breweries, and fitness facilities may operate at fifty percent capacity. ${ }^{100}$ In response to the state's argument that its orders should be upheld under Jacobson, Justice Alito wrote:

It is a mistake to take language in Jacobson as the last word on what the Constitution allows public officials to do during the COVID-19 pandemic. Language in Jacobson must be read in context, and it is important to keep in mind that Jacobson primarily involved a substantive due process challenge to a local ordinance requiring residents to be vaccinated for small pox. It is a considerable stretch to read the decision as establishing the test to be applied when statewide measures of indefinite duration are challenged under the First Amendment or other provisions not at issue in that case. ${ }^{101}$

Justice Kavanaugh went further, saying, "There are certain constitutional red lines that a State may not cross even in a crisis. Those red lines include racial discrimination, religious discrimination,

\footnotetext{
${ }^{93}$ Masterpiece Cakeshop Ltd. v. Colorado Civil Rts. Comm'n, 138 S. Ct. 1719 (2018).

${ }^{94}$ Burwell v. Hobby Lobby Stores, Inc., 134 S. Ct. 2751 (2014) (applying the federal Religious Freedom Restoration Act instead of the First Amendment); Zubik v. Burwell, 136 S. Ct. 1557, 1558-58 (2016) (same).

${ }^{95}$ South Bay United Pentacostal v. Newsom, 140 S. Ct. 1613 (2020) (per curiam)

${ }^{96} I d$. at 1613 (Roberts, C.J., concurring).

${ }^{97} I d$. at 1613 (Kavanaugh, J., dissenting)

${ }^{98} I d$. at 1613 (Roberts, C.J., concurring).

${ }^{99}$ Calvary Chapel Dayton Valley v. Sisolak, 140 S. Ct. 2603 (2020) (denying injunction).

${ }^{100} I d$. at 2605 (Alito, J., dissenting).

${ }^{101} I d$. at 2608 (Alito, J., dissenting).
} 
and content-based suppression of speech." 102 In his view, when a state creates categories that favor some but not other similar entities, it must place religious entities in the favored category, granting religion something like a "most favored nation status," absent a compelling reason to do otherwise. ${ }^{103}$

The four dissenting Justices in Calvary Chapel appeared to redefine and increase the importance of the constitutional right to religious freedom. ${ }^{104}$ In their view, claims of violations of discrimination against religion should normally be subject to strict scrutiny whenever religion is limited more than some secular entities, even when the law does not target religion, even when there are good reasons for different treatment, and even in an emergency. Their view became the majority after Justice Ruth Bader Ginsburg died on September 18, 2020, ${ }^{105}$ and Amy Coney Barrett became the ninth Justice on October 26, 2020. ${ }^{106}$

Roman Catholic Diocese of Brooklyn v. Cuomo ${ }^{107}$ confirmed that a new majority of Justices would apply strict scrutiny to claims of religious freedom. That case considered two challenges to New York Governor Andrew Cuomo's executive order that imposed different limits on the number of people who could gather in person for non-essential purposes, based on the number of COVID cases in each area or zone of the state. The Roman Catholic Diocese of Brooklyn and Agudath Israel of America argued that limits of ten persons in red zones and twenty-five persons in orange zones violated their religious freedom. ${ }^{108}$ The executive order did not single out religious groups for special treatment, but also did not include them in the state's list of "essential" businesses or services. A majority of the Justices agreed that labeling religious services non-essential treated religion differently from other similar activities and was not neutral toward religion. ${ }^{109}$ Therefore, they concluded, strict scrutiny was the standard of review. While the state's interest in controlling the pandemic was "unquestionably a compelling interest," the majority held that the regulations were not "narrowly tailored" to prevent the spread of COVID. ${ }^{110}$ In particular, the majority found that limiting church attendance to ten or twenty-five people was inconsistent with allowing hundreds of people to shop in grocery or other stores. It thus enjoined enforcement of the order pending resolution of the case on its merits. But by deciding that the strict scrutiny standard of review that applied, the ultimate outcome was preordained. ${ }^{11}$

The South Bay case (South Bay II) returned to the Supreme Court in 2021, after California Governor Newsom reimposed limits in light of a surge in COVID cases. ${ }^{112}$ Indoor attendance at worship services, restaurants, and move theaters were limited to the lesser of twenty-five percent

\footnotetext{
${ }^{102} I d$. at 2614-15 (Kavanaugh, J., dissenting).

${ }^{103} \mathrm{Id}$. at 2612 (Kavanaugh, J., dissenting).

${ }^{104} I d$. at 2610 (Kavanaugh, J., dissenting) (laying out four categories of laws affecting religion and his view of the corresponding standards of review).

${ }^{105}$ Supreme Court of the United States, Press Release (Sept. 18, 2020), https://www.supremecourt.gov/publicinfo/press/ pressreleases/pr_09-18-20.

${ }^{106}$ Barbara Sprunt, Amy Coney Barrett Confirmed to Supreme Court, Takes Constitutional Oath, NPR (Oct. 26, 2020), https://www.npr.org/2020/10/26/927640619/senate-confirms-amy-coney-barrett-to-the-supreme-court.

${ }^{107}$ Roman Catholic Diocese of Brooklyn v. Cuomo, 141 S. Ct. 63 (2020) (per curiam) (consolidated with Agudath Israel of America v. Cuomo granting injunction against enforcement of New York executive order pending disposition of an appeal in federal court of appeals).

${ }^{108}$ The Roman Catholic Diocese churches each seated at least 500 people, and two seated over 1,000. Id. at 67.

${ }^{109}$ The court showed considerable sympathy with the belief that Catholic and Orthodox Jewish faiths required attending worship in person, even though other religious groups were streaming services online. $I d$. at 68

${ }^{110} I d$. at 67.

${ }^{111}$ Lower court decisions upholding restrictions on worship attendance were vacated and remanded with instructions to reconsider in light of Roman Catholic Diocese. See, e.g., Robinson v. Murphy, 141 S. Ct. 972 (2020) (remanded for reconsideration in light of Roman Catholic Diocese).

${ }^{112}$ South Bay United Pentecostal Church v. Newsom (South Bay II), 141 S. Ct. 716 (2021). See also Gateway City Church v. Newsom, 141 S. Ct. 1460 (2021) (per curiam) (denying injunctive relief based on South Bay II); Harvest Rock Church, Inc. v. Newsom, 141 S. Ct. 1289 (2021) (per curiam) (enjoining ban on indoor worship in Tier 1 high risk COVID areas).
} 
of building capacity or one-hundred persons. ${ }^{113}$ In a one-paragraph per curiam decision, the Court enjoined enforcement of the indoor limits on worship-except the twenty-five percent capacity limit-pending resolution of the merits of the case in the lower court. ${ }^{114}$ It allowed enforcement of the ban on singing indoors. Importantly, all Justices agreed that the state has a compelling interest in reducing the risk of coronavirus infection. Chief Justice Roberts, concurring, reiterated his position that "federal courts owe significant deference to politically accountable officials." 115 But this time he was unwilling to defer to their judgment that a complete ban on indoor worship was necessary. The South Bay cathedral, with room for 1,000 people, was large enough to safely accommodate more than one-hundred worshippers. "Deference, though broad, has its limits," he concluded. ${ }^{116}$ Justice Gorsuch would enjoin all the restrictions, indicating that even "subtle departures from neutrality" toward religion trigger strict scrutiny. ${ }^{117}$

Justice Kagan dissented, joined by Justices Breyer and Sotomayor. Notably, she did not rely on Jacobson or any emergency standard of review. Instead, she argued that the other Justices were comparing apples and oranges: "The 'Constitution does not require things which are different in fact ... to be treated in law as though they were the same." 118 By treating "worship services like secular services that pose a much lesser danger," such as running in and out of a hardware store, she wrote, the Court's decision "defies our case law, exceeds our judicial role, and risks worsening the pandemic." 119 The majority was not insisting on neutrality toward religion, in her opinion, but favoring religion at the expense of scientific expertise and public health.

The Justices hardened their positions when considering yet another modified executive order from California in Tandon v. Newsom. ${ }^{120}$ Governor Gavin Newsom's order limited all religious and secular gatherings inside homes to members of no more than three households. The lower courts denied an injunction sought by pastors who wished to host bible study groups and worship at home. ${ }^{121}$ The Supreme Court reversed and granted the temporary injunction in a four page per curiam decision, with the same three Justices dissenting. ${ }^{122}$ That opinion concluded that the state failed to prove that requiring home worship events to use precautions like those required for retail and entertainment venues would not suffice to prevent the spread of COVID. Thus, the order was not narrowly tailored to avoid unnecessary restrictions on religion and failed the strict scrutiny test.

Despite the obvious disagreement among the Justices over the standard of review in prior cases, the per curiam opinion asserted that the Court's decisions have made three points clear:

First, government regulations "trigger strict scrutiny under the Free Exercise Clause, whenever they treat any comparable secular activity more favorably than religious exercise.... Second, whether two activities are comparable for purposes of the Free Exercise clause must be judged against the asserted government interest that justifies the regulation at issue....

\footnotetext{
${ }^{113}$ The rules prohibited indoor attendance at bars, concerts, sporting events, family entertainment centers, and theaters, while retail stores, except grocers, were limited to fifty percent capacity. South Bay United Pentecostal Church v. Newsom, 494 F. Supp. 3d 785 (S.D.Cal. 2020).

${ }^{114}$ The prohibition applied to all public gatherings, but only in areas of the state with the highest rates of coronavirus infection. People were permitted to gather outdoors in California's mild climate. Thus, the crowd size, but not the activity, was limited in those areas. South Bay II, 141 S. Ct. at 721 (Kagan, J., dissenting).

${ }^{115} \mathrm{Id}$. at 716 (Roberts, C.J., concurring).

${ }^{116} \mathrm{Id}$. at 717 .

${ }^{117} I d$. at 717 (Gorsuch, J., statement, joined by Thomas and Alito).

${ }^{118} \mathrm{Id}$. at 720 (Kagan, J., dissenting).

${ }^{119} I d$. at 720 .

${ }^{120}$ Tandon v. Newsom, 141 S. Ct. 1294, 209 L. Ed. 2d 355, 359 (2021) ("This is the fifth time the Court has summarily rejected the Ninth Circuit's analysis of California's COVID restrictions on religious exercise.”).

${ }^{121}$ Tandon v. Newson, 992 F.3d 916 (9th Cir. 2021).

${ }^{122}$ Tandon, 209 L. Ed. 2d at 359 (Justice Kagan, J., joined by Justices Breyer and Sotomayor, dissent for the reasons stated in South Bay II).
} 
Third, .... narrow tailoring requires the government to show that measures less restrictive of the First Amendment activity could not address its interest in reducing the spread of COVID. Where the government permits other activities to proceed with precautions, it must show that the religious exercise at issue if more dangerous than those activities even when the same precautions are applied.... Otherwise, precautions that suffice for other activities suffice for religious exercise too." 123

Chief Justice Roberts reported, without opinion, that he would deny the injunction. Justice Kagan, joined by Justices Breyer and Sotomayor, would also deny the injunction. Reprising her dissent in South Bay II, Justice Kagan wrote that the executive order limited all in-home gatherings, whether secular or religious, to three households, properly treating like things alike. ${ }^{124}$ By comparing home worship with hardware stores and nail salons, she said, the majority improperly treated unlike things the same. Worse, she wrote, the Court "once more commands California 'to ignore its experts' scientific findings,' thus impairing 'the State's effort to address a public health emergency."' 125

These decisions suggest that a majority of current Supreme Court Justices may have used the coronavirus cases as an opportunity to redefine the standard of review to afford religious rights increased protection from government regulation. The changes are subtle. First, they found that an otherwise generally applicable law was not neutral toward religion if the law imposed fewer restrictions on "any comparable secular activity." The key to finding a lack of neutrality lay in the choice of which secular activities the Justices considered comparable. Different treatment of religion can be reasonable or unreasonable, depending upon whether the facts justify different treatment. In these cases, the Justices appeared to ignore facts in the record about COVID transmission in retail and religious activities. Instead, they relied on their own assumptions about the risk of infection to find similarities and differences.

\section{F. Implications for Judicial Review in Non-Emergencies}

The five Justices who consistently voted to enjoin restrictions on religious worship attendance appear to privilege religious freedom over other rights affected by public health restrictions. This new majority of Justices also appears to believe that the standard of review during the pandemic is the same standard that applies during ordinary circumstances, as seen in their choice of strict scrutiny as the applicable standard. ${ }^{126}$ A pandemic may give government a compelling interest in preventing the spread of disease, but any limits on religious activities must be narrowly tailored to advance that interest while infringing on the right as little as possible. ${ }^{127}$ Justice Gorsuch wrote, "Even in times of crisis-perhaps especially in times of crisis-we have a duty to hold governments to the Constitution." 128 In other words, there is no emergency standard of review, at least for religious claims.

In contrast, two appellate courts in cases involving reproductive health care clinics did conclude that Jacobson established a general standard of review or "framework" for emergencies.

\footnotetext{
${ }^{123} 141$ S. Ct. at1296-1297, 209 L. Ed. 2d at 357-58.

${ }^{124}$ South Bay II, 141 S. Ct. at 1298, 209 L. Ed. 2d at 360 (Kagan, J., dissenting).

${ }^{125} I d$. at 360 .

${ }^{126}$ See Calvary Chapel, 140 S. Ct. at 2604 (Alito, J., dissenting, joined by Thomas and Kavanaugh) ("The problem is no longer one of exigency, but one of considered yet discriminatory treatment of places of worship."); 140 S. Ct. at 2609 (Gorsuch, J., dissenting) ("The world we inhabit today, with a pandemic upon us, poses unusual challenges. But there is no world in which the Constitution permits Nevada to favor Caesars Palace over Calvary Chapel.").

${ }^{127}$ See text accompanying supra, notes 97, 117, and 122 .

${ }^{128}$ South Bay II, 141 S. Ct. at 718 (Gorsuch, J., statement joined by Thomas and Alito).
} 
Because the Supreme Court vacated all four appellate court decisions in the reproductive rights cases, whether or not they relied on Jacobson, without any opinion explaining its reasons, it remains unclear whether the Supreme Court would adopt an emergency standard of review just for reproductive rights. It seems more likely that the new majority of Justices would simply lower the level of scrutiny for laws restricting the right to make reproductive decisions, effectively relegating that right to a lesser status, with or without an emergency. ${ }^{129}$

Four indicators suggest that the Court may be using these COVID cases as vehicles to initiate changes in the ordinary standard of judicial review beyond emergencies. First, the new majority of Justices distinguished the right to religious freedom under the First Amendment from substantive due process rights based on the liberty protected by the Fourteenth Amendment, which include the right to terminate a pregnancy. Justice Gorsuch, concurring, wrote, "Government is not free to disregard the First Amendment in times of crisis." ${ }^{30}$ Justice Kavanaugh posited three "red lines that a State may not cross even in an emergency." 131 Notably, he did not include Fourteenth Amendment substantive due process rights. Instead, he argued that "courts should be extremely deferential to the States when considering a substantive due process claim by a secular business that it is being treated worse than another business" and cited Jacobson. ${ }^{132}$ Jacobson decided a substantive due process liberty claim. This suggests that at least four Justices would not necessarily apply the ordinary standard from Casey and Whole Woman's Health during an emergency. ${ }^{133}$ However, because they appear to apply the ordinary standard in cases involving other rights, they may be signaling a change in the ordinary standard for abortion cases, one that would be more deferential to the state and less protective of a woman's right.

Second, the majority indicated that even temporary restrictions on religious freedom during a pandemic inflicted a cognizable injury on worshippers. One requirement for litigants seeking a preliminary injunction is to demonstrate that they would be subjected to "irreparable injury" if the challenged order were not enjoined pending litigation on the merits. ${ }^{134}$ In Roman Catholic Diocese, the majority wrote, “The loss of First Amendment freedoms, for even minimal periods of time, unquestionably constitutes irreparable injury." 135 This contrasts with the now vacated Abbott $V$ decision, which made no mention of the possibility that the loss of a Fourteenth Amendment substantive due process right could constitute irreparable injury. The lack of access to abortion services, even for a week or so, can extend pregnancy beyond the time within which abortions are legal under state law. Abortion delayed often means abortion denied, which is denial of the right. Moreover, women who traveled out of state for abortion services faced the risk of contracting COVID, itself a clear injury.

Third, the Justices opinions suggest that a majority will see unconstitutional discrimination against religion in many laws that would have been upheld as neutral and generally applicable in the past. They found discrimination against religion in facially neutral COVID orders by selecting particular activities and rejecting others for comparison with worship services. For example, California's executive order in Tandon was facially neutral; it limited all in-home gatherings to

\footnotetext{
${ }^{129}$ On May 17, 2021, the Court agreed to review a non-emergency Mississippi law prohibiting pre-viability abortions after 15 weeks - except health emergencies and fetal abnormalities - that a federal appeals court held unconstitutional under current law in Dobbs v. Jackson Women's Health Org., 945 F.3d 265 (5th Cir. 2019). Amy Howe, Court to Weigh in on Mississippi Abortion Ban Intended to Challenge Roe v. Wade, SCOTUSblog (May 17, 2021), https://www.scotusblog.com/2021/05/courtto-weigh-in-on-mississippi-abortion-ban-intended-to-challenge-roe-v-wade/.

${ }^{130}$ Roman Catholic Diocese, 141 S. Ct. at 69 (Gorsuch, J., concurring).

${ }^{131}$ See text accompanying supra, note 102.

${ }^{132}$ Calvary Chapel, 140 S. Ct. at 2614 (Kavanaugh, J., dissenting).

${ }^{133}$ See text accompanying supra, notes 63 and 64.

${ }^{134}$ Supra, note 65.

${ }^{135}$ Roman Catholic Diocese, 141 S. Ct. at 68 (quoting Elrod v. Burns, 427 U.S. 347 (1976)).
} 
three households. The majority instead compared in-home religious gatherings not to in-home political and social gatherings, but to shopping in commercial buildings. They concluded that in-home religious gatherings suffered from discrimination, because some retail businesses could accept a large number of people who went in and out. ${ }^{136}$ This allowed them to conclude that the order was not neutral, but discriminated against religion, which required strict scrutiny. As Justice Kagan wrote in Tandon, "the per curiam's analysis of this case defies the factual record." 137 In South Bay II, she wrote that the majority "insists on treating unlike cases, not like ones, equivalently." 138

Finally, the Justices appear inconsistent in their demands of the litigants, complaining that states had not provided enough evidence of the need for restrictions on religion, while speculating about the likelihood of transmission in religious and secular activities. ${ }^{139}$ To be sure, there were instances of states unadvisedly allowing economically powerful industries to open with larger capacities than religious gatherings. The best example is that of casinos in Nevada. ${ }^{140}$ However, equating worship services with banks and grocery stores seems inaccurate and disingenuous. In the reproductive clinic cases, courts varied in their reliance on the factual record. Abbott $V$ and In re Rutledge accepted the states' arguments that the clinics could jeopardize the PPE supply, while rejecting or ignoring the evidence that clinic closures would harm women, depriving many, if not most, of their access to abortion. On the other hand, Slatery and Robinson took the evidence of harm more seriously and issued a preliminary injunction against clinic closures. If the Court uses facts to decide whether a constitutional right is violated, it should get the facts right, especially in an emergency when lives may be at stake. ${ }^{141}$ If facts can be misperceived or manipulated to achieve a preferred outcome, the integrity of judicial review is at risk.

\section{G. Conclusion}

U.S. Supreme Court decisions in the above cases illustrate the potential for emergencies to alter protection for human rights indefinitely. There are good reasons why emergencies should not suspend ordinary judicial review, as Wiley and Vladeck explain, especially in an extended crisis. ${ }^{142}$ The idea of suspending the rules may appeal in a short-term crisis, such as a hurricane or explosion. ${ }^{143}$ In long lasting emergencies, however, exceptions can settle into daily life and become the rule.

\footnotetext{
${ }^{136}$ Tandon, 992 F.3d at 925, noting that even if religious gatherings in homes were compared to small businesses, those businesses were also subject to extensive requirements for cleaning, ventilation, and mask wearing.

${ }^{137}$ Tandon, 209 L. Ed. 2 d at 360 (Kagan, J., dissenting).

${ }^{138}$ Pentecoastal Church, 141 S. Ct. at 722 (Kagan, J., dissenting).

${ }^{139} 141$ S. Ct. at 723 (Kagan, J., joined by Breyer and Sotomayor dissenting) ("In the worst public health crisis in a century, this foray into armchair epidemiology cannot end well."); Roman Catholic Diocese, 141 S. Ct. at 79 (Sotomayor, J., joined by Kagan, dissenting) ("Justices of this Court play a deadly game in second guessing the expert judgment of health officials about the environments in which a contagious virus, now infecting a million Americans each week, spreads most easily.").

${ }^{140}$ Calvary Chapel, 140 S. Ct. at 2613 (Kavanaugh, J., dissenting) Nevada did "not have a persuasive public health reason for treating churches differently from restaurants, bars, casinos, and gyms."

${ }^{141}$ Gonzales v. Carhart, 550 U.S. 124, 165 (2007) (The "Court retains an independent constitutional duty to review factual findings where constitutional rights are at stake.").

${ }^{142}$ Wiley \& Vladeck, supra, note 38 at $182-83$ (suspension is inappropriate for long-lasting emergencies; most case outcomes are the same with or without suspending ordinary standards; judicial review is needed to hold government accountable).

${ }^{143}$ See Smith v. Avino, 91 F.3d 105 (11th Cir. 1996) (upholding curfew after hurricane).
} 
In the religion cases, no Supreme Court Justice claimed to suspend the rules. No Justice suggested a special emergency standard of review. Nevertheless, in presenting their views of the ordinary standard, the majority of Justices changed the rules. The changes may be subtle, but they are likely to last, with significant implications for both constitutional law and public health. ${ }^{144}$

The Justices disagree over how much weight to give certain constitutional rights and when they are being infringed. But, a likely majority now gives religious freedom presumptively superior status among constitutional rights. The religion cases shift judicial review of claims of religious freedom to an even stricter standard by finding discrimination against religion in even neutral and generally applicable laws. They do so by discounting scientific evidence and making questionable comparisons between religious and secular activities. Far less scrutiny is likely to be accorded claims of violations of liberty in future, especially the right to terminate a pregnancy. Comments in dictum argue that such substantive due process rights should receive minimum scrutiny whereby judges defer to government claims of public health benefits regardless of evidence to the contrary.

Judicial review of emergency measures is necessary and valuable because it can operate as a check on government overreaching or using a crisis as pretext to achieve political or ideological goals. ${ }^{145}$ It also puts the judiciary in the position of controlling the scope of emergency powers. ${ }^{146}$ For both reasons, the judiciary should ensure that its own standards of review avoid ideological predilections and factual errors. Human rights, public health, and the integrity of an independent judiciary depend on it.

\footnotetext{
${ }^{144}$ After this Article was written, the Supreme Court held that a city contract with private adoption agencies discriminated against religion by requiring all agencies to allow same-sex married couples to foster children in compliance with the city's anti-discrimination law. The Court held that the contract did not qualify as "generally applicable" because it authorized the city to make exceptions - although none had ever been made - and therefore violated the religious beliefs of Catholic Social Services, which opposed same-sex marriage. Fulton v. City of Philadelphia, 2021 U.S. LEXIS 3121 (2021).

${ }^{145}$ Wiley \& Vladeck, supra, note 38, at 183; Ilya Somin, The Case for "Regular" Judicial Review of Coronavirus Emergency Policies, Volokh ConsPiracy (Apr. 15, 2020), https://reason.com/2020/04/15/the-case-for-normal-judicial-review-ofcoronavirus-emergency-policies (ordinary judicial review defends against unnecessary deprivations of rights).

${ }^{146}$ See John Fabian Witt, American Contagions: Epidemics AND the LaW From SMallpox to COVID-19 (2020) (arguing that recent decisions preferring religion over public health shifts control of emergencies from the states to the federal government).
}

Cite this article: Mariner WK (2021). Shifting Standards of Judicial Review During the Coronavirus Pandemic in the United States. German Law Journal 22, 1039-1059. https://doi.org/10.1017/glj.2021.51 